\title{
Strategic Issues in Dam Operation and Maintenance in Indonesia
}

\author{
Abdul Malik Sadat Idris ${ }^{1}$ \\ Angga Sukmara Christian Permadi ${ }^{2}$ \\ Unika Merlin Sianturi ${ }^{3}$ \\ Frieda Astrianty Hazet ${ }^{4}$ \\ Ministry of National Development Planning/Bappenas - Indonesia
}

\begin{abstract}
Strategic issues in dam operation and maintenance are important to meet domestic water needs and the study was conducted by the Dam Operational Improvement and Safety Project (DOISP) in two phases. DOISP Phase I was established to continue the Dam Safety Program with the focus on the operational improvement and the safety of dams. The Dam Operational Improvement and Safety Project Phase II (DOISP Phase II) is a continuation of DOISP Phase I that previously has provided support to the completion of remedial and rehabilitation works and operational and safety improvement of 34 dams owned the Ministry of Public Works and Housing (MPWH) as well as the preparation of various guidelines which relate to the dam management operation. Strategic issues in operation and maintenance are prepared in 2020-2024, strategic plan by the Directorate of Water Resources and Irrigation (Ministry of National Development Planning/Bappenas). Planning based on strategic issues in operation and maintenance is important because a dam and reservoir can support hydropower, navigation, recreation, flood control, irrigation, and water supply, with each multipurpose benefit having a significant social and economic impact at the local level, regional and national.
\end{abstract}

Keywords: Dam; DOISP ; Strategic Plan.

\footnotetext{
${ }^{1}$ Abdul Malik Sadat Idris is the Director of Water Ressouces and Irrigation, Ministry of National Development Planning/Bappenas RI.

${ }^{2}$ Angga Sukmara Christian Permadi is a staff of Flood Management in Selected River Basin (FRSMB), Directorate of Water Ressouces and Irrigation, Ministry of National Development Planning/Bappenas RI. E-mail: anggasukmarao8@gmail.com, Indonesia.

${ }^{3}$ Unika Merlin Sianturi is a Planner Staff, Directorate of Water Ressouces and Irrigation, Ministry of National Development Planning/Bappenas RI.

${ }^{4}$ Frieda Astrianty Hazet is a Junior Planner, Directorate of Water Ressouces and Irrigation, Ministry of National Development Planning/Bappenas RI.
} 
Abdul Malik Sadat Idris, Angga Sukmara Christian Permadi,

Unika Merlin Sianturi, and Frieda Astrianty Hazet

\title{
Strategic Issues in Dam Operation and Maintenance ind Indonesia
}

\author{
Abdul Malik Sadat Idris, Angga Sukmara Christian Permadi, Unika Merlin \\ Sianturi, and Frieda Astrianty Hazet
}

\section{Introduction}

The water use on a global scale will increase faster than the increase in the global population itself. World consumption will increase due to the growing prosperity of the population. The 2030 Water Resources Group Report states that the global water needs for agriculture in the year 2030 will reach 4500 billion $\mathrm{m} 3$ compared with the current state of about 3100 billion m3. Currently, there are many countries that have taken groundwater faster than filling back. If this continues then by 2030 two-thirds of the world's population will live in areas vulnerable to water. Energy costs, food costs, turbulence in the global economy and disasters have a critical connection related to water resources. Substitution rainy and dry season in Indonesia is an example of the limitations of nature. The change of climate patterns are erratic, the threat of floods and drought is the main reason for Indonesia to continue to maintain and improve the function of the dams or reservoirs. The role of dams as a water source for raw water, irrigation, electricity generation and also flushing the city increasingly seen as an important strategic and supporting livelihood of many people.

The Indonesian Government has recently addressed water-food-energy nexus in its formal policy framework, which is applied in the country's programs, such as in constructing 61 new dams all across the country. The total amount of existing dams in Indonesia is now more than 213 large dams and 182 dams were owned and managed by the Ministry of Public Works and Housing. It means Indonesia will have a total 274 large dams in the next five years. However most of the existing dams in Indonesia are categorized as the old dam. This condition is giving the Indonesian Government a big challenge to maintain, operate and ensure the safety of a lot of old dams. Based on the Government Planning year 2014-2019, in the next 5 years the number of dams to be managed by the Ministry of Public Works and Housing will increase with 61 new dams. The new dams will be constructed in several rivers within the country in order to make reservoirs necessary for providing raw water supply for agriculture irrigation, hydro-electrical power generation (PLTA), clean water for municipal and industrial uses for mitigation and control the flood, and for environmentally flushing the rivers in the urban area, etc.

The main objective of constructing the dam and its reservoirs is to support the Government policies that relate to food, water supply, and energy securities. Besides the development of new dams, the functionality, sustainability, and safety of the existing dams should also be maintained, upgraded and optimally improved to guarantee the effective continuation of their contribution in the achievement of the said Government policies. The improvement, optimally and sustainability function and safety program of the dams will cover about 140 units of existing large dams located in many provinces of Indonesia. These efforts are mainly due regard to the predicted risk of dam failure that may occur that is being the subject of various 
special regulations that relate to the safety of the people living in the downstream parts of the dams.

The Dam Operational Improvement and Safety Project (DOISP) Phase I was established to continue the Dam Safety Program with the focus on the operational improvement and the safety of dams. At the end of the DOISP Phase, I program, although the activities have been fulfilled, some of the project objectives have not been achieved. It still leaves some activities to improve the success of the operation and safety of the dam as well as the establishment of the dam regulations.

The Dam Operational Improvement and Safety Project Phase II (DOISP Phase II) is a continuation of DOISP Phase I that previously has provided support to the completion of remedial and rehabilitation works and operational and safety improvement of 34 dams owned the Ministry of Public Works and Housing as well as the preparation of various guidelines which relate to the dam management operation. DOISP Phase I have also covered some preparation activities for dam rehabilitation works to be implemented DOISP Phase II. The project will increase the safety and the functionality of its reservoir with respect to bulk water supply of a total amount of 140 existing dams owned by the Government of Indonesia (mostly by the Ministry of Public Works and Housing) located all over the country: in the Province of Aceh, Lampung, West Java, Banten, Central Java, D.I Yogyakarta, East Java, Bali, East Kalimantan, South Sulawesi, Maluku, West Nusa Tenggara and East Nusa Tenggara.

\section{Conceptual Basic}

The discussion of strategic issues in operation and maintenance in the Dam Operational Improvement and Safety Project (DOISP) study should be based on strategic management. This is because maintenance is carried out based on the issues found in studies conducted in the field. Therefore, strategic management is very relevant to be used as a basis for thinking in the study of strategic issues in operation and maintenance. Regarding strategic management, there are two relevant understandings of the issues discussed, namely the understanding of Hunger and Wheelen, and Fred R. David's understanding.

Hunger and Wheelen (1996) explain that strategic management is a series of managerial decisions and actions that determine the performance of a company or organization in the long run. Based on this, strategic management is very important to formulate the long-term performance of a program. Strategic management can also be interpreted as art and knowledge to formulate, implement, and evaluate cross-functional decisions that make an organization able to achieve its objectives (Fred R. David, 2004). From this point of view, it clearly shows that strategic management is so important in achieving the goals of a program that has been formulated previously.

Fred R. David (2004) stresses that strategic management can be defined as the science of the formulation, implementation, and evaluation of cross-functional decisions that enable an organization to achieve its objectives. Based on this understanding, strategic management basically emphasizes the formulation of an optimal performance program. Complementing the understanding of Fred R. David, Hunger and. Wheelen (1996), explaining strategic management is basically a set of managerial decisions and actions that determine the long-term implementation of a company. This includes an overview of the environment (both external and internal), formulation strategies (long-term strategy/planning), implementation 
strategies, evaluation, and control). Of the two understandings can be a relevant basis for the discussion of discussion about strategic issues in operation and maintenance.

\section{Methodology}

The discussion of strategic issues in operation and maintenance is relevant reviewed using the methodology of observation. Denzin \& Lincoln (2009) explained that observation is the first step towards a wider focus of attention, namely participant observation, to the observation of practical results as a method in its own capacity. Observations are made to obtain a real picture of an event or event to answer research questions. Observation is basically a methodology that can be traced to the establishment of the theoretical root of the interactionist-symbolic method because in collecting data, researchers can simultaneously interact with the subject of their research. Adding to this explanation, Ciesielska and Jemielniak (2018) assert that observation is the main method in a project or one of several complementary qualitative methods.

In terms of participant observation, Denzin \& Lincoln (2009) asserted that participant observation in the interactionist-symbolic perspective uses more intense interactions with research subjects. Observation in this perspective can also influence pure observation, even though the resulting answer makes it and to some extent more suitable with the scope of ethnomethodology. In addition to participant observation, discussion of strategic issues in operation and maintenance is also relevant to be studied by group observation. Regarding group observations, Bungin (2007) explains that group observations are observations made by a group of research teams on an issue raised as an object of research. So the discussion of strategic issues in operation and maintenance is relevant to be studied by the method of participant observation and group observation.

\section{Result, Analysis, and Discussions}

\subsection{Dam Safety Governance}

The Dam Safety Program brings the Indonesian government awareness regarding the dam operational and maintenance improvement, not only the safety aspect. The Dam Operational Improvement and Safety Project (DOISP) 1 was established to continue the Dam Safety Program with the focus on the operational improvement and the safety of dams. At the end of the DOISP 1 program, although the activities have been fulfilled, some of the project objectives have not been achieved. It still leaves some activities to improve the success of the operation and safety of the dam. A similar condition also happened in the dam regulations. Since the Law No. 7 year 2004 was canceled by the Indonesian Constitutional Court in 2013, the government regulation regarding the dam management is ruled by the MPWH through two regulations related to Water Resources and Dam. MPWH issued of Ministry Regulation No. 01 / PRT / M / 2016 about Water Resources and Ministry Regulation No. 27 / PRT / M / 2015 on Dam. Those regulations are less sufficient compare with the previous regulation when the dam management was regulated by the Government Regulation Level (PP). Therefore the improvement in dam regulation and policy is still needed.

To complete some of the activities DOISP 1 left behind on the first stage, the Indonesian Government decided to start again with the 2nd Phase of DOISP 
starting from the middle of 2017 to end of 2022, with a total project duration of 6 years. DOISP 2 will emphasize physical rehabilitation of dams, also further improvement of operational and safety aspects of dams. Based on the DOISP 1 evaluation, from 140 dams of the scope of work is divided into five components showed the consistency and sustainability of DOISP 1 . Although in the DOISP 2 components is almost the same as DOISP 1 , the DOISP 2 components will more emphasis on rehabilitation work of existing dams. The DOISP 2 provides more funding for remedial and rehabilitation works The dams sub-sector thus faces several unresolved needs as indicated below (Directorate of Water Resources and Irrigation, Ministry of National Development Planning):

1. Strengthening DGWR's Dam Management Units and National Dam Safety Assurance Institutions taking account of the new statutory framework.

2. Developing National Expertise in Dam Engineering and Management.

3. Improvement of Dam Remedial Works Design and Construction Quality Assurance.

4. Expansion of Dam Safety Assurance to Privately-Owned Dams and Mine Tailings Dams.

5. Reducing Deferred Maintenance Due to Inadequate O\&M Budgets

6. Resolution of Hydrology and Design Flood Issues

7. Implementation of Emergency Action Plans.

8. Reduction of Reservoir Sedimentation Damages and Risks.

9. Dam Portfolio Assessment for Remedial Works and O\&M Budget Prioritization.

10. There is thus a need to formulate and prepare a new project for Dam Operational Improvement and Safety to address the above

There is an opportunity to further improve the operationalization of emergency action plans. An effective emergency action plan is a living document to be revised and updated as new information about the reservoir and downstream area becomes available or the people involved in the notification process change. Continuous coordination between the River Basin Organizations (RBOs), local government, and emergency management authorities, as well as simulation exercises to test the plans, would provide the necessary input to keep the emergency action plans up-to-date and benefit the execution in the event of dam failure. Another area that requires attention is the emergency action plans for dams located in river basins with multiple dams. Currently, these plans do not take account.

\subsection{Dam Strategic Plan 2020-2024}

Discussion on strategic issues in operation and maintenance in the preparation of the program is thoroughly reviewed by the Directorate of Water Resources and Irrigation/Bappenas (2018) by preparing a strategic plan for 20202024. There are several challenges in the future regarding the construction and management of dams in Indonesia. Some of the challenges between these are:

1. Service demands to meet the needs of raw water and drinking water, irrigation to meet the needs of food security, and hydropower as a renewable energy source. These three needs will increasingly increase the quantity and quality over the years along with Indonesia's population growth which will continue to increase. 
2. Demands for dam performance and safety performance from disaster risk due to dam failure. Dam risk in Indonesia is quite large with the number of dams in Indonesia that have entered a relatively old age (over 20 years).

3. Demands for improvement in OP management, conservation of upstream dam areas, and application of new technologies to optimize dam benefits and safety.

4. Demands for integrated development and utilization of multi-purpose water reservoirs for cities, agriculture, and electricity

5. Demands for multi-use dam support for economic zones and smelter industries in accordance with regional developments in Indonesia.

Some of the challenges above have been thought of by Bappenas as a state institution that is concerned with national development planning, especially the construction and management of dams. The above challenge has prompted Bappenas to design a strategy for the future development and management of dams in Indonesia. Some of these strategies are contained in the 2010-2024 RPJM draft, the drafting process is ongoing and is expected to be completed around October before a new president is set. Some of these strategies include:

1. Provision of raw water/drinking water from the dam through

a. Dam connection with WTP

b. Utilizing the capacity of raw water from dams that have not been utilized

2. Multi-purpose pool planning to support SEZ / KI Regions and Smelter Industries in Indonesia

a. Official document planning for the development of multi-purpose dams to support SEZ / IEC and Smelter Industries.

b. The pilot project for the development of multi-purpose water reservoirs in supporting industrial activities. (North Kalimantan, Southeast Sulawesi, North Sumatra, Papua)

3. Development and utilization of multi-purpose water reservoirs in an integrated manner for cities, agriculture and electricity

a. Guidelines for developing and utilizing multi-purpose water reservoirs in an integrated manner.

b. Pilot project for the development and utilization of multi-purpose water reservoirs in an integrated manner. (PPP scheme, Central Kalimantan, Banten, West Java, Central Java, East Java, South Sulawesi, West Sulawesi, East Nusa Tenggara, West Nusa Tenggara, and Papua)

c. Per capita water storage capacity.

d. Hydropower capacity from the reservoir.

e. Provision of raw water sourced from new reservoirs.

f. Development of PPPs to provide electricity in existing dams.

4. Improved Dam Operation \& Security Performance

a. Dams with catchment areas that have protected area functions $>10 \%$.

b. The government-owned dam has a green belt area.

c. Dam that has an operating permit.

d. Dams that have basic dam safety facilities.

e. Increasing and restoring reservoir service capacity through the application of new technology.

f. Formation of UPB specifically at each government-owned dam. 
5. Development and utilization of dams on a target based on needs analysis and choice analysis, and development of PPP schemes.

a. Development feasibility assessment using international standard protocols or guidelines.

b. Support for completion of the 65 new dam program.

c. Simplification of permits for construction of new dams.

d. Making investment guidelines for the development of multi-purpose storage with consideration of functions and stakeholders.

e. Application of PPP schemes for the construction of new dams and utilization of existing dams.

f. Review of the efficiency of utilizing existing dams for irrigation due to the impact of land-use change.

g. Additional benefits of existing dams for raw water and electricity.

6. Increased OP management, conservation of upstream dam areas, and the application of new technologies.

a. Management of dam watershed conservation by various relevant stakeholders, especially the community.

b. Application of dam upgrading technology for additional dam volumes.

c. Registration of dam assets as BMN in the Ministry of Finance to facilitate the initiation of the implementation of a performance-based contract for dam management.

d. Data synchronization and issuance of Operating Permits for dams in Indonesia.

e. Strengthening dam institutions through improving the quality of human resources, infrastructure, and dam management SOPs in accordance with the PUPR Regulation on guidelines for establishing UPB.

f. RTRW rearrangements from upstream to downstream dams to maximize conservation, utilization, and mitigation of the risk of dam failure.

7. Increasing the number and efficiency of reservoirs for irrigation

a. Support for completion of the 65 Ministry of PUPR dam program.

b. Increased efficiency of allocation of SSS reservoir water for irrigation.

\subsection{Dam Operation, Maintenance, and Safety Improvement}

As a massive infrastructure, dams should be managed carefully. Errors in management can result in the loss of many lives. There are several challenges to dam management in Indonesia. The main things raised include issues regarding operations, maintenance, and safety, as well as the steps, should be taken to manage those issues. These issues are explained below.

\section{a. Dam Database}

The recording of dams data in Indonesia still requires better attention. At the level of dam name only, each institution still has different data. For example, dam data in Directorate of Operation and Maintenance of the Ministry of PUPR (Dit. Bina OP Kemen-PUPR) is different from the dam data at the Dam Authority (Balai Bendungan). There are at least 18 dams not recorded in the database of Balai Bendungan but recorded in Dit Bina OP database. Conversely, there are 9 dams that are not recorded in the database of Dit Bina OP but are recorded in the database of Balai Bendungan. From other information, it is known that there are at least 3 dams 
Abdul Malik Sadat Idris, Angga Sukmara Christian Permadi, Unika Merlin Sianturi, and Frieda Astrianty Hazet

that were not recorded in the two institutions. A summary of the differences is shown in the table below.

Table 1. Recapitulation Dams List Data in Bina OP and Balai Bendungan

\begin{tabular}{|l|l|l|}
\hline $\begin{array}{l}\text { Recorded in Bina OP, } \\
\text { not recorded in Balai } \\
\text { Bendungan }\end{array}$ & $\begin{array}{l}\text { Recorded in Balai } \\
\text { Bendungan, not } \\
\text { recorded in Bina OP }\end{array}$ & $\begin{array}{l}\text { Not recorded in } \\
\text { Bina OP and Balai } \\
\text { Bendungan }\end{array}$ \\
\hline Banda & $\begin{array}{l}\text { Canggah } \\
\text { Cungkup }\end{array}$ & Nongsa \\
\hline Batu Tulis & Jompong & Baloi \\
\hline Blimbing & Mantar & Sei Pulai \\
\hline Brambang & Nglambangan & \\
\hline $\begin{array}{l}\text { Gegurik } \\
\text { Gembong (BBWS BS) }\end{array}$ & Parang Joho & \\
\hline Inen Ratu & Waworoda & \\
\hline Jago & Wera I & \\
\hline Jerowaru & West Extention & \\
\hline Jurang Dao & & \\
\hline Kembar II & & \\
\hline Kuangrundun & & \\
\hline Pejanggik & & \\
\hline Propok Batu Tinja & & \\
\hline Rawa Jombor & & \\
\hline Tanju & & \\
\hline Tundak & & \\
\hline Wringin Jenggot & & \\
\hline
\end{tabular}

Source: Ministry of Public Works and Housing

Unclear data on dams can have an impact on policymaking for each dam. In the DOISP Phase II program alone, there were 11 dams that were not recorded in the Dit Bina OP database. The impact of the absence of these 11 dams in the database is that they did not include the 11 dams at the annual work plan (AWP) of each Balai (PIU). Most Balai argued that the dams were actually small dams and it is not urgent to repair/rehabilitate it using DOISP funds.

Table 2. List Dam In PIP/Project Implementation Plan (Not In O\&M Directorate Data List Dams)

\begin{tabular}{|l|l|}
\multicolumn{1}{|c|}{ Dam } & \multicolumn{1}{|c|}{ Manager/Balai } \\
\hline Kd. Waru & BBWS Pemali Juana \\
\hline Mantar & BWS Nusa Tenggara I \\
\hline Waworada & BWS Nusa Tenggara I \\
\hline Wera I & BWS Nusa Tenggara I \\
\hline Livuhahani & BWS Nusa Tenggara II \\
\hline Nglambangan & BBWS Bengawan Solo \\
\hline Canggah & BBWS Bengawan Solo \\
\hline Cungkup & BBWS Bengawan Solo \\
\hline Manyar & BBWS Bengawan Solo \\
\hline Parang Joho & BBWS Bengawan Solo \\
\hline Muara & BWS Bali Penida \\
\hline
\end{tabular}

Source: Directorate of Water Resources and Irrigation/Bappenas 
Based on information obtained from various sources, it is known that the differences in dam databases may happen due to the existence of new standards in determining the status of large dams listed in PUPR Regulation No 27 the Year 2015. To ascertain the status of each dam, some Balais are currently taking the initiative to re-measure the reservoirs, so that accurate volume, height, and risk (which are the basic criteria for large dam status based on PUPR Regulation No. 27 Year 2015) can be obtained.

\section{b. Amount and Ownership of Dams}

Dam databases in several institutions still vary, so the number of dams is still uncertain. The data currently used as a reference is data in Dit Bina OP. The data states that the number of government-owned dams is 192 dams, with 7 dams are newly constructed ones as part of "new 65 dams program". In the 2017-2018 period, there were 10 new dams that had been constructed, so that the number of government dams as of December 2018 was 202. The number of non-government dams, owned by private companies and state-owned companies, was 32 . Thus, the total number of existing dams in Indonesia is 234 dams.

\section{c. Age of Dam}

Dams in Indonesia are dominated by dams that are quite old (20-50 years) with a large number of old dams (over 50 years old). Of the total 234 dams, 7 dams are more than 100 years old, 36 dams are 50-100 years old, 117 dams are 20-50 years old, and 73 dams are less than 20 years old. Because of the large number of old dams, operations and maintenance activities need to be taken seriously, especially to ensure the safety of the downstream area of the dam.

\section{d. Operation Permit}

In accordance with PUPR Regulation No.27 of 2015, the implementation of dam operations is carried out based on dam operation permits issued by the Minister. As of 2018, only 16 dams have operating licenses from 202 government-owned dams.

Table 3. List of Dams have Operating Permit

\begin{tabular}{|l|l|l}
\hline No & Dams & Manager \\
\hline 1 & Sermo & BBWS Serayu Opak \\
\hline 2 & Tilong & BWS Nusa Tenggara II \\
3 & Wonorejo & Perum Jasa Tirta I \\
\hline 4 & Djuanda & Perum Jasa Tirta II \\
\hline 5 & Batu Bulan & BWS Nusa Tenggara I \\
6 & Batutegi & BBWS Mesuji Sekampung \\
\hline 7 & Sangiran & BBWS Bengawan Solo \\
\hline 8 & Tibu Kuning & BWS Nusa Tenggara I \\
9 & Keuliling & BWS Sumatera I \\
\hline 10 & Benel & BWS Bali Penida \\
\hline 11 & Grokgak & BWS Bali Penida \\
12 & Telaga Tunjung & BWS Bali Penida \\
13 & Jatibarang & BBWS Pemali Juana \\
14 & Lahor & Perum Jasa Tirta I \\
15 & Karangkates & Perum Jasa Tirta I
\end{tabular}

The Indonesian Journal of Development Planning

Volume III No. 2 - August 2019 
Abdul Malik Sadat Idris, Angga Sukmara Christian Permadi, Unika Merlin Sianturi, and Frieda Astrianty Hazet

16 Kalola BBWS Pompengan Jeneberang

Source: Directorate of Water Resources and Irrigation/Bappenas

\section{e. Operation and Maintenance of Human Resources}

Government-owned dams have limited quantity and quality of human resources. There are still dams which are only operated by fewer than five officers. In addition, the average level of education of those officers is only high school.

\section{f. Availability of Funds for Operation and Maintenance}

The funds available for the operation and maintenance of dams are relatively small. The average funds available from the APBN are 900 million rupiahs per year per dam.

\section{g. Risk Score of Dam}

There are many dams that are in the high-risk category in terms of safety. Of the 35 dams that have passed through the risk assessment in DOISP I activities, 28 dams $(80 \%)$ are at high risk.

\section{h. Sedimentation}

The total volume of reservoirs in Indonesia has been reduced by $20 \%$ due to sedimentation. Java Island is the area with the largest reduction in reservoir volume, with a percentage of $30 \%$. The sedimentation rate in 19 Indonesian dams studied in DOISP I, reached $0.8 \%$ per year; much faster than the sedimentation rates of other countries in Asia, which is $0.3 \%$.

\section{i. Dam Outcome}

The function of the dam is still dominated by the fulfillment of water for irrigation and is dominated by the characteristics of a single purpose. Efforts that have been made by the government to address those issues are reflected in activities/projects to improve the operation, maintenance and security of dams. In 1998-2003 a Dam Safety Program (DSP) activity was funded by the World Bank to improve the function and safety of dams through increased dam operation and maintenance. The program was then continued in 2009-2017 through the activities of the Dam Operational Improvement and Safety Project (DOISP) which focused on 34 dams. In 2017-2023, the DOISP activity was continued as a DOISP Phase II program to continue the program that had not been fully implemented and increase the number of dams to 140 dams. The government through the Dit Bina OP has also prepared a strategic plan for dam management. Activities to improve dam operations and security included in the plan include:

- Rationalization of Instruments (Piezometer, Inclinometer, V-Notch, Seismograph, Microtremor, Vibration Sensor)

- Periodic updating of Safety Components (Inspection, Reservoir Operation Patterns, O \& M Guidelines, RTD)

- Fulfillment of Minimum O \& M Facilities and Infrastructures

- Improvement and Optimization of Reservoir Services

- Capacity Building(UPB Institution and Officers)

- $\quad$ Real-time monitoring 
- Empowering upstream and surrounding communities

Dam monitoring activities include activities on the upstream and downstream sides of the dam. On the upstream side, monitoring activities include real-time monitoring activities for weather conditions, inflow, travel time, sediment control, and observation of water quality. On the downstream side, monitoring activities include monitoring of water availability, water requirements, planting plan, and water control points. In dams, monitoring activities include visual inspection, monitoring instrumentation, monitoring water quality and availability, and monitoring sedimentation.

\subsection{The Economic Benefit of Multi-Purpose Dam}

There are six data categories that structure the multipurpose benefits framework (Bonet, 2015). These categories are referred to herein as "uses", and they represent a culmination of operations and services made possible due to the existence of a reservoir. These uses are broadly classified to identify categories associated with a reservoir project, and serve as a foundation for assessing collective and inter-dependent relationships (Bonet, 2015):

1. Hydropower: Operation and use of generating facilities and/or equipment for producing power by the sole source of water.

2. Flood Control: Dams that facilitate the prevention and/or lessen the severity of flood damage to valuable resources within a flood basin.

3. Navigation: The operation and control of locks to facilitate the transportation of goods via inland waterways.

4. Recreation: The use of water bodies (reservoirs or rivers) for physical and recreational activities (boating, fishing, swimming, etc.).

5. Water Supply: Public and private withdrawals of water used for consumption, municipal, and industrial needs.

6. Irrigation: The withdrawal and use of water from reservoirs to meet the needs and requirements for crop and plant irrigation to sustain growth and production.

Uses can be complementary, as in the release of minimum flows to sustain navigation draft, aquatic health, and recreation activities, competing, when hydroelectric generation is foregone to manage reservoir levels for flood control by releasing spillway flows, or inter-dependent, as in the release of deep cool reservoir water through hydropower turbines for use downstream in thermoelectric operations. Each of these uses may have a valuable inter-dependent economic benefit. Within a multipurpose benefit valuation framework, however, each unique use is often identified and valued individually. The challenge inherent to this methodology is that water is consumed both on-stream and off-stream, it is valued explicitly and implicitly, and valuation metrics are often not comparable across uses (Bonet, 2015).

Local community needs should always be considered when establishing the multipurpose dam's benefits, in addition to how the benefits should be prioritized amongst the various users. Further steps include dam site identification and an environmental impact assessment as appropriate. Calculations on water retention capacity, flow rates and minimum water requirements for various uses should be conducted for planning purposes. Socio-economic and environmental evaluations should be conducted at the selected sites, and criteria should be established to monitor potential community and environmental changes after construction. Dam 
designs vary, and the chosen design is agreed upon between planners and construction engineers. Operational management includes flushing out sediments and monitoring selected environmental and socioeconomic variables, amongst other activities. $^{5}$

Based on the availability of both public and proprietary data, the following represent the several methodologies that can be used to compute the economic benefit of each multipurpose use.

\section{- $\quad$ Hydropower}

To quantify hydropower generation, the total annual kilowatt-hours of energy production from a power plant are multiplied by the average wholesale rate at which it is sold. Depending on their business model, each agency provided an average rate for either an individual plant or a group of plants. The unit price for energy varies between and within the agencies as they cater to different regions of the nation, each with unique energy markets and demand.

\section{- $\quad$ Flood Control}

Flood control benefits are quantified as damages avoided, or the reduction in potential or realized damages to structures, contents of structures, and land use in areas that would have been inundated had the structure not been in place. Flood plain curves, using geographic and local data, allow both the acreage and depth of a prevented flood to be estimated. When a dam regulates a flooding event, the volume stored is used in the flood plain model. A fraction of the value of land, buildings, goods, and activities that lie within the flood plain and would have been destroyed are assigned to the flood event based on its severity. This ultimately allows a dollar amount of potential damages to be reached.

\section{- $\underline{\text { Recreation }}$}

Reservoirs are popular destinations for a wide variety of recreation activities including fishing, boating, camping, swimming, water sports, and wildlife observation. Three common procedures are available to estimate recreation spending: the travel cost method (TCM), the contingent valuation method (CVM), and unit day values. TCM models assume the travel and time costs spent by visitors to get to a reservoir increase with distance. A demand curve is derived that values the reservoir using travel and time as 'price' surrogates. The CVM relies on surveys that ask an individual their willingness to pay for recreation activities (for which they are not currently paying) at a given location. The unit day value approach assumes the total benefit of the reservoir can be estimated by multiplying the number of visitors to the reservoir by the average amount spent per visitor per trip. Visitation data is produced from surveys and regional economic and population models, while spending profiles are generally obtained via direct survey.

\section{- Irrigation}

The benefit for irrigation is quantified by multiplying the total acres of land irrigated by the value of crops grown on those acres.

\footnotetext{
${ }^{5}$ Climate Change Adaptation Technologies for Water. Multipurpose Dams. UN Environment-DHI Centre on Water and Environment.
} 
Abdul Malik Sadat Idris, Angga Sukmara Christian Permadi, Unika Merlin Sianturi, and Frieda Astrianty Hazet

\section{- Water Supply}

To produce water supply uses, the volume of water stored for municipal and industrial use is multiplied by the national average price of water per unit volume. In general, contractors and municipalities reserve a volume of water under contract to be made available each year for their consumption. This data are largely found within project operating plans that outline the storage allocations of each reservoir, or in public reports on water use.

Several publications of the economic benefit of the multi-purpose dam have been published. One of the examples is Cumberland River System multipurpose projects in USA, which has found that recreation is the one that gives big portion of benefit. Multi-purpose dams, if well planned and managed, provide an important option for meeting some of today's major development challenges. By providing clean and reliable energy, storage volume to improve drinking water supply or agricultural food production, and enhanced flood control, they contribute to energy, water, and food security--and to human security in general. Invulnerable regions, multi-purpose dams can also be an appropriate response to the impacts of climate change. Yet, as many new multi-purpose projects are expected to be realized in the future, the sustainability of large dams and reservoirs will remain a key issue (Agriwaterpedia, 2016).

\section{Conclusion}

A dam and reservoir may support hydropower, navigation, recreation, flood control, irrigation, and water supply, with each multipurpose benefit providing significant social and economic impacts on a local, regional, and national level. Most of the dam in Indonesia is still single purpose reservoirs for irrigation. There are potential to develop other functionality in several existing dam, especially for supporting hydropower and recreations. It needs a robust study and preparation to develop a single purpose to multi-purpose reservoirs. Operating rules, management practices, consumer demands, and environmental constraints must all be balanced to meet the multipurpose project's objectives. Therefore, an in-depth study was carried out on the strategic issues in dam operation and maintenance discussed in the 2020-2024 strategic plan so that the dam can not only benefit the people's lives in daily life but can also provide economic benefits for the community.

Until 2018, there have been 17 new dams that have been built and are targeted to have 12 other dams completed in 2019. In 2023, it is targeted that all dams from the 65 dam program will be completed. Dam that has completed the construction process generally does not operate immediately. This is due to several things, such as the need for a licensing process; such as tamping permits and operating licenses, the need for infrastructure development services; such as irrigation channels, as well as the process of cooperation in terms of utilization for bulk water and electricity. Dam Operational management is still one of the challenges in its implementation, both related to the adequacy of the budget, the quality, and quantity of personnel, and other operational issues. One alternative to improve the quality of operational activities in dams is to submit operational processes to third parties under the scheme of Performance-Based Contracting (PBC). The big purpose of the in-depth study of strategic issues in operation and maintenance by DOISP in two phases is to provide good services to the community. 
Abdul Malik Sadat Idris, Angga Sukmara Christian Permadi, Unika Merlin Sianturi, and Frieda Astrianty Hazet

\section{References}

Agriwaterpedia. 2016. Multipurpose dams. Available at: http://agriwaterpedia.info/wiki/Multi-purpose_dams

Bungin, M. Burhan. 2007. Penelitian Kualitatif: Komunikasi, Ekonomi, Kebijakan Publik, dan Ilmu Sosial Lainnya. Jakarta: Kencana Prenada Media Group.

Bonnet, M., et al. 2015. The Economic Benefit of Multipurpose Reservoirs in the United States-Federal Hydropower Fleet. Oak Ridge National Laboratory.

Ciesielska, M. dan D. Jemielniak (ed). 2018. Qualitative Methodologies in Organization Studies. https://doi.org/10.1007/978-3-319-65442-3_2

Climate Change Adaptation Technologies for Water. Multipurpose Dams. UN Environment-DHI Centre on Water and Environment.

David, Fred R. 2004. Manajemen Strategis: Konsep-Konsep. Jakarta: PT Indeks Kelompok Gramedia.

Denzin, Norman K. and Yvonna S. Lincoln. (ed). 2009. Handbook of Qualitative Research, 2nd editions, New Delhi, Teller Road Thousand Oaks, California, USA: Sage Publication, Inc.

Directorate of Water Resources and Irrigation, Ministry of National Development Planning (Bappenas), 2018

Directorate Bina OP and Balai Bendungan, Ministry of Public Works and Housing, 2018.

Hunger, J. David and Thomas L. Wheelen. 1996. Strategic Management.USA: Addison-Wesley Publishing Company. 